\title{
Рівень фізичного розвитку, Функціонального стану і здоров'я студентів медичного вищого навчального закладу з гіпермобільністю суглобів
}

\author{
О. Б. Неханевич, В. Б. Бакурідзе-Маніна
}

\author{
ДЗ «Дніпропетровська медична академія МОЗ України», Дніпропетровськ, \\ Україна
}

\begin{abstract}
Резюме. Цель исследования - изучение влияния повышенной подвижности в суставах на показатели физического развития, функционального состояния, физической подготовленности и физического здоровья студентов медицинского вуза. Нами была обследованы студентки I-II курса Днепропетровской медицинской академии в возрасте 17-20 лет, которые по состоянию здоровья были определены в основную медицинскую группу. В работе доказано негативное влияние фактора гиперподвижности в суставах на исследуемые показатели, что требует коррекции нагрузок во время физического воспитания студентов с повышенной гибкостью.

Ключевые слова: физическое развитие, гиперподвижность, суставы, физическая работоспособность, физическая подготовленность, физическое здоровье.
\end{abstract}

\begin{abstract}
Summary. The purpose of investigation is studying the hypermobility in joints influence on indicators of physical development, functional condition, physical readiness and physical health of students of medical high school. We had been surveyed 51 student I-Il courses of the Dnepropetrovsk medical academy at the age from 17 till 20 years which on a state of health have been distributed in the basic medical group. In work is proved the negative influence of hypermobility in joints on investigated indicators that demands correction of loadings during physical training of students with the raised flexibility.
\end{abstract}

Key words: physical development, hypermobility, joints, physical working capacity, physical readiness, physical health.

Вступ. Процес навчання у сучасному вищому навчальному закладі (ВН3) характеризується динамічністю, високою інтенсивністю, підвищеним об'ємом навчальних технологій, що висуває високі вимоги до стану здоров'я студентів, який, в свою чергу, залежить від соціально-економічних та гігієно-екологічних умов, харчування, відпочинку, умов життя, рівня культури, освіти, стану охорони здоров'я та медичної науки, від ступеня рухової активності людини.

Мета фрізичного виховання полягає у підготовці всебічно розвиненої особистості, здатної до побутової та трудової діяльності [5].

Ефективність занять з фрізичного виховання залежить не тільки від стану основних функціональних систем організму та фрізичної підготовки, а й від конституційних особливостей людини, проявами яких $\epsilon$ антропометричні параметри та фрізіометричні показники. На думку багатьох спеціалістів, саме ці дані можуть виступати як критерії для визначення оптимального об'єму фрізичних навантажень $[9,11,13]$. Маючи достатню інфоормацію про особливості фрізичного розвитку, а саме стану опорно-рухового апарату, можна запобігти небажаних скарг та травматизації при виконанні фрізичних вправ.

Однією 3 індивідуальних особливостей організму, яка дозволяє виконувати рухові дії 3 великою амплітудою, $\epsilon$ гнучкість. Під гнучкістю розуміють морфофрункціональні властивості опорно-рухового апарату, які визначають рухливість його ланок. Мірою гнучкості $\epsilon$ амплітуда рухів у суглобах [6]. Деякі автори [4, 10] відзначають, що на заняттях з фрізичного виховання можна швидко домогтись результатів у розвитку гнучкості, але розвивати ії до граничних величин немає потреби. Багато науковців вказують на те, що надмірна розтягнутість м'язів, зв'язок та сухожиль може призвести до нестабільності опорно-рухового апарату, а отже - до травмування та негативних наслідків $[3,4,7]$. Тому високий рівень розвитку гнучкості $\epsilon$ одним із основних чинників, що, з одного боку, забезпечує достатню фрізичну підготовленість та спортивну майстерність, з іншого, підвищує вірогідність отримання травм опорно-рухового апарату $[1,7]$. 
Відомості науково-методичної літератури свідчать, що підвищена гнучкість, або гіперрухливість, у суглобах може бути не тільки результатом фрізичних тренувань, а й спадковим фрактором, який впливає на фрізичний розвиток та стан здоров'я. Вона може бути відображенням системних патологічних процесів формування, дозрівання та деградації сполучної тканини 3 ураженням життєво важливих внутрішніх органів (серця, крупних судин та ін.). Тому підвищена гнучкість може стати критерієм відбору для подальшого та поглибленого медичного обстеження $[1,2]$.

Дана робота виконувалась у відповідності 3 планом ініціативної науково-дослідної теми «Медичне забезпечення спортивних, оздоровчих та відновних тренувань» (номер держреєстрації 0111U001374) кафредри фрізичної реабілітації, спортивної медицини та валеології ДЗ «Дніпропетровська медична академія MO3 України».

Мета дослідження - враховуючи сказане у вступі - це вивчення впливу підвищеної рухливості у суглобах на показники фрізичного розвитку, фрункціонального стану, фрізичної підготовленості та фрізичного здоров'я студентів медичного BH3.

Для досягнення поставленої мети було поставлено такі завдання:

1) визначити поширеність ознак гіперрухливості суглобів серед студентів медичної академії;

2) дослідити особливості фрізичного розвитку, функціонального стану, фрізичної підготовленості та фрізичного здоров'я студентів;

3) встановити вплив підвищеної рухливості у суглобах на показники фрізичного розвитку, фрізичної працездатності, фрізичної підготовленості та фрізичного здоров'я студентів.

Матеріали та методи дослідження. Для вирішення поставлених завдань нами обстежено студенток I-II курсу ДЗ «Дніпропетровська медична академія МОЗ України». За станом здоров'я їх було віднесено до основної медичної групи, де вони займалися за програмою фрізичного виховання для медичних ВНЗ. У дослідженні взяли участь студентки у віці від 17 до 20 років (51 особа) - в середньому $18,9 \pm 0,1$ років.

Для постановки проблеми ми провели аналіз науково-методичної літератури за останні 10 років, за допомогою анкетування отримали дані щодо самооцінки здоров'я, а фрізичний розвиток досліджували антропометричним методом. Клінічні ознаки гіпермобільності діагностувались за критеріями Бейтона [12] за дев'ятибальною шкалою (за кожну позитивну ознаку додавали по одному балу). Діагностично значущими вважалися: пасивне розгинання п'ятого пальця кисті в п'ястно-фраланговому суглобі більш, ніж $90^{\circ}$ з обох боків; пасивне приведення першого пальця кисті до долонної поверхні на обох руках; пасивне перерозгинання нижніх та верхніх кінцівок в колінних та ліктьових суглобах відповідно більш, ніж на $10^{\circ}$; з вихідного положення стоячи - згинання тулуба вперед з доторканням долонь обох рук до підлоги. Оцінку проводили за наступною шкалою: 0-3 бали - нормальна рухливість у суглобах, 4-6 - помірно виражена гіпермобільність, 7-9 балів - значна гіпермобільність суглобів.

Рівень фізичного здоров'я досліджували за методикою Г. Л. Апанасенка, де за бальною шкалою оцінювались масо-ростовий та силовий індекси, життєвий показник, подвійний добуток і час відновлення частоти пульсу після 20 присідань за 30 с. Фізичну працездатність оцінювали за допомогою тесту Руфф'є [3].

Оцінка фрізичних якостей проводилась із застосуванням тестів 3 фрізичної підготовленості: розвиток силових показників - за даними тесту «згинання та розгинання рук в упорі лежачи на підлозі»; розвиток якості швидкості - за часом бігу на 30 і 60 м та плавання на 25 м, швидкісносилові якості - за допомогою тесту «стрибок у довжину 3 місця», витривалість - за даними 12-хвилинного бігу, спритність - за даними човникового бігу 4 × 9 м, силову витривалість - за тестом «піднімання тулуба з положення лежачи за 1 хв».

Статистичну обробку отриманих результатів здійснювали за допомогою пакета ліцензійних прикладних програм STATISTICA (6.1, серійний номер AGAR909E415822FA. Аналізували вид розподілу показників за допомогою W-критерію Шапіро-Уілка. Визначали достовірності відмінностей між показниками 3 урахуванням типу розподілу за допомогою $\mathrm{t}$-критерію Стьюдента U-критерію Манна-Уітні для кількісних показників і критерію $\chi$-Пірсона - для якісних. Встановлюючи взаємозв'язок між фоакторами, застосовували кореляційний аналіз за показником Пірсона або Спірмена. Для визначення впливу фракторів, що досліджуються, на групи обстеження використовували дисперсійний аналіз ANOVA/MANOVA. Пороговим рівнем статистичної значущості отриманих результатів було взято $\mathrm{p}<0,05)$ [8].

Результати дослідження та їх обговорення. При дослідженні рухливості у суглобах у студентів за методикою Бейтона ми визначили, що в середньому показник становить 4,6 \pm 0,4 бала, що загалом відповідає середньому ступеню рухливості. Залежно від рівня вираженості 
ТАБЛИЦЯ 1 - Розподіл студенток у групах порівняння за рівнями фізичної працездатності

\begin{tabular}{|l|c|c|c|}
\hline $\begin{array}{c}\text { Рівень } \\
\text { працездатності }\end{array}$ & $\begin{array}{c}\text { Група I } \\
(\mathbf{n = 1 4 )}\end{array}$ & $\begin{array}{c}\text { Група II } \\
(\mathbf{n = 1 4 )}\end{array}$ & $\begin{array}{c}\text { Група III } \\
(\mathbf{n}=\mathbf{9})\end{array}$ \\
\hline Низький & 7,5 & - & $22,0^{*}$ \\
\hline Нижче середнього & 21,0 & $64,0^{*}$ & 12,0 \\
\hline Середній & $50,0^{*}$ & 21,0 & 44,0 \\
\hline Вище середнього & 7,5 & $7,5,0$ & 22,0 \\
\hline Високий & $14,0^{*}$ & $7,5,0$ & - \\
\hline
\end{tabular}

${ }^{\star}-p<0,05$

суглобових проявів студенток розподілили таким чином: до першої групи віднесли осіб із легким ступенем рухливості у суглобах - 18 студенток $(35,3 \%)$, до групи II - 22 (43,1 \%) студентки із середнім ступенем рухливості та до групи III - 11 $(21,6 \%)$ студенток, які мали виражену ступінь рухливості суглобів.

Аналіз морфометричних даних вказував на значне зниження силових показників за результатами кистьової динамометрії у представниць II та III груп. Спостерігалась статистично значиме зниження силового індексу у студенток із середнім та вираженим ступенями рухливості, що склало 35,4 \pm 2,9 та 33,5 \pm 3,4 кг відповідно, у порівнянні зі студентками з легким ступенем рухливості суглобів (43,5 $\pm 3,3$ кг, р > 0,05).

При вивченні фрізичної працездатності за тестом Руф'є було встановлено, що у студенток групи II цей показник дорівнює 10,5 \pm 1,0 балів, а групи III - 10,5 \pm 1,2 балів, що загалом відповідає рівню нижче середнього. Вони мали достовірно нижчі показники, ніж у першій групі $-8,6 \pm 0,8$ балів ( $<0,05)$, що відповідає середньому рівню фрізичної працездатності. Для встановлення різниці в групах за якісними рівнями фрізичної працездатності було застосовано критерій $\chi^{2}$-Пірсона. Результати аналізу вказали на статистично значуще збільшення представниць 3 високим та середнім рівнями фрізичної роботоздатності серед першої групи, натомість у другій та третій групах було більше студенток із рівнями нижче середнього та низьким відповідно. Розподіл студенток за рівнем працездатності наведено у таблиці 1.

За допомогою проведеного аналізу результатів тестування рухових якостей ми отримали дані, що свідчать про вплив на

$*-p<0,05$. них об'єму рухів у суглобах. Для цього ми провели однофакторний дисперсійний аналіз, де як фрактор, що впливає, було обрано ступінь рухливості у суглобах (табл.2).

Дані таблиці 2 вказують на залежність основних показників фрізичної підготовленості від якості гнучкості. Це підтверджує думку багатьох науковців, які відносять гнучкість до базових якостей.

У інших показниках фрізичної підготовленості не було достовірної статистичної різниці, однак ми виявили тенденцію до погіршення результатів у студенток, що відносилися до груп з середнім та вираженим ступенями рухливості у суглобах. Також ми аналізували дані щодо зв'язку показників гнучкості з рівнем здоров'я. За методом анкетування ми запропонували студенткам оцінити рівень свого здоров'я. При аналізі даних опитування було виявлено, що студентки з другої та третьої груп оцінюють рівень свого здоров'я значно нижче у порівнянні зі своїми однолітками 3 першої групи. Ці дані підтвердились статистичними методами, де достовірно гірший показник був у студенток, які мали середній ступень (7,5 \pm 0,5 бала) та виражений ступінь рухливості у суглобах (7,7 \pm 1,0 бала) порівняно зі студентками з легким ступенем рухливістю у суглобах (8,6 \pm 0,8 бала, $р<0,05)$.

Ці дані співпадали з результатами при дослідженні фрізичного здоров'я студенток за методикою Г. Л. Апанасенка. Так, у середньому у першій групі рівень здоров'я становив 7,7 \pm 0,7 бала, що статистично значуще більше, ніж в другій та третій групах (6,2 \pm 0,7 бала та 6,0 \pm 0,6 бала відповідно, $р<0,05)$.

ТАБЛИЦЯ 2 - Аналіз рухових якостей у групах порівняння

\begin{tabular}{|c|c|c|c|}
\hline Рухові якості & $\begin{array}{l}\text { Група I } \\
(\mathrm{n}=18)\end{array}$ & $\begin{array}{l}\text { Грyпа II } \\
(\mathrm{n}=22)\end{array}$ & $\begin{array}{c}\text { Група III } \\
(\mathrm{n}=11)\end{array}$ \\
\hline $\begin{array}{l}\text { Силові показники за тестом «зги- } \\
\text { нання та розгинання рук в упорі } \\
\text { лежачи на підлозі», од }\end{array}$ & $23,0 \pm 2,3^{*}$ & $18,6 \pm 1,3$ & $18,6 \pm 0,7$ \\
\hline $\begin{array}{l}\text { Якості швидкості за часом, с: } \\
\text { бігу на } 30 \text { м } \\
\text { бігу на } 60 \text { м } \\
\text { плавання на } 25 \text { м }\end{array}$ & $\begin{array}{c}4,7 \pm 0,1^{*} \\
9,9 \pm 0,2^{*} \\
29,01 \pm 0,01^{*}\end{array}$ & $\begin{array}{c}5,1 \pm 0,1 \\
10,4 \pm 0,2 \\
35,02 \pm 0,02\end{array}$ & $\begin{array}{c}5,1 \pm 0,2 \\
10,7 \pm 0,2 \\
37,13 \pm 0,04\end{array}$ \\
\hline $\begin{array}{l}\text { Швидкісно-силові якості за тестом } \\
\text { «стрибок у довжину з місця», см }\end{array}$ & $193,1 \pm 17,0^{*}$ & $180,7 \pm 4,5$ & $178,5 \pm 6,1$ \\
\hline $\begin{array}{l}\text { Витривалість за часом 12-хвилин- } \\
\text { ного бігу, м }\end{array}$ & $2229,4 \pm 137,1^{*}$ & $1930,5 \pm 109,8$ & $1810,0 \pm 126,9$ \\
\hline $\begin{array}{l}\text { Силова витривалість за тестом } \\
\text { «піднімання тулуба з положення } \\
\text { лежачи за } 1 \text { хв», од }\end{array}$ & $40,9 \pm 1,7^{*}$ & $36,1 \pm 1,6$ & $38,0 \pm 1,4$ \\
\hline $\begin{array}{l}\text { Спритність за даними «човниково- } \\
\text { го бігу» } 4 \times 9 \text { м, с }\end{array}$ & $10,5 \pm 0,2^{*}$ & $11,1 \pm 0,1$ & $11,2 \pm 0,2$ \\
\hline
\end{tabular}




\section{Висновки}

1. Встановлено, що середній показник рухливості у суглобах дівчат становить 4,6 \pm 0,4 бала, що відповідає середньому ступеню.

2. У студенток, яких віднесено до груп з середнім та вираженим ступенями рухливості у суглобах, силовий індекс, фрізична працездатність та самооцінка здоров'я достовірно нижчі, ніж у студенток з легким ступенем рухливості у суглобах.

3. Доведено, що у студенток, які мають виражену рухливість у суглобах, показники швидкості, сили, швидкісно-силових якостей, витривалості та рівень фрізичної підготовленості достовірно нижчі, про що свідчать показники тестів на швидкість (біг на 30 та 60 м та плавання на 25 м), на витривалість (біг за 12 хв), на швидкісно-силові якості (стрибок у довжину), на спритність

\section{Література}

1. Алтер М. Дж. Наука о гибкости / Майкл Дж. Алтер. - К.: Олимп. лит., 2001. - 423 с.

2. Беленький $A$. Г. Гипермобильный синдром - системное невоспалительное заболевание соединительной ткани / А. Г. Беленький // Новости медицины и фармации. 2007. - № 3 (207). - С. 3-4.

3. ГригороВич Е. С. Физическая культура / Е. С. Григорович, В. А. Переверзев //Вышэйш. шк. - Минск, 2009. $245 \mathrm{c}$.

4. Ильинич В. И. Физическая культура студента: учебник / В. И. Ильинич. - М. : Гардарики, 2005. - С. 228-229.

5. Лоза T. Пошук шляхів підвищення рівня здоров'я студентів: теоретичний аспект / Т. Лоза // Спорт. вісн. Придніпров'я. - 2012. - № 2. - С. 33-36.

6. Романенко В. А. Диагностика двигательных способностей: учеб. пособие / В. А. Романенко. - Донецк: Изд-во ДонНУ, 2005. - С. 73-78.

7. Руда I. Є. Аналіз локалізації травм опорно-рухового апарату в аспекті спеціальних вимог до розвитку гнучкості в художній гімнастиці / І. Є. Руда, В.Ю.Сосіна / / Молода спорт. наука України. - 2009. - Т. 3, Вип. 13, - С. 150-153.

8. Халафяян A. A. STATISTICA 6. Статистический анализ данных / А. А. Халафян. - М.: ООО «Бином-Пресс», 2007. -512 c.

9. ХаритоноВа Л. Г. Дисплазия соединительной ткани и ее значимость в процессе физического воспитания и занятий спортом / Л. Г. Харитонова // Теория и практика физ. культуры. - 2010. - № 7. - С. 29-33.

10. Шиян Б. М. Теорія і методика фрізичного виховання школярів. Ч. 1. / Б. М. Шиян. - Тернопіль: Навч. кн., 2012. - C. 224-233.

11 Garcia-Campayo J. Joint hypermobility and anxiety: the state of the art / J. Garcia-Campayo, E. Asso, M. Alda // Curr. Psychiatry Rep. - 2011. - Vol. 13(1). - P. 18-25.

12. Grahame R. The revised criteria for the diagnosis of benign joint hypermobility syndrome (BJHS) / R. Grahame, H. A. Bird, A. Child / / J. of Rheumatology. - 2000. - Vol. 27, N7. - P. 1777-1779.

13. Knee function in 10-year-old children and adults with generalised joint hypermobility / B. Juul-Kristensen, H. Hansen, E. B. Simonsen [et el.] // Knee. - 2012. - P. 12. («човниковий біг») та на силу («згинання та розгинання рук в упорі лежачи на підлозі»).

4. Негативний вплив фрактора гіперрухливості у суглобах на показники фрізичного розвитку, функціонального стану, фрізичної підготовленості та фрізичного здоров'я потребує корекції навантажень під час фрізичного виховання студентів із підвищеною гнучкістю.

Перспективи подальших досліджень полягають у більш поглибленому вивченні стану здоров'я студентів з вираженим ступенем рухливості у суглобах, зіставленні зовнішніх ознак гіперрухливості суглобів зі змінами у внутрішніх органах та системах, що може говорити про системність враження сполучної тканини та розробку індивідуального підходу до навчальнотренувального процесу у таких студентів.

\section{References}

1. Alter M. D. A science about flexibility / M. D. Alter. Kiev: Olympiyskaya literatura, 2001. - 423 p.

2. Belenkyi $A$. G. The Hypermobile syndrome - system not inflammatory disease of connective tissue / A. G. Belenkyi // Medicine and Pharmacy News. - 2007. - N 3 (207). P. 3-4.

3. Grigorovich E. S. Physical culture / E. S. Grigorovich, V. A. Pereverzev // Minsk, 2009. - 245 p.

4. Ilinich V. I. Physical culture of student: Textbook / V. I. Ilinich. - Moscow: Gardariki, 2005. - P. 228-229.

5. Loza T. Searching for increasing ways of students health: theoretical aspects / T. Loza / / The Sports Herlander of Pridneprovya. - 2012. - N 2. - P. 33-36.

6. Romanenko V. A. Diagnostics of impellent abilities. Textbook / V. A. Romanenko. - Donetsk: Publishing house of Donetsk Nat. Univ., 2005. - P. 73-78.

7. Ruda I. Analyse of trauma location in aspect of special requirements for flexibility development in rhythmic gymnastics / I. Ruda, V. Sosina // The Young sports science of Ukraine. - 2009. - Vol. 3, N. 13. - P. 150-153.

8. Halafyan A. A. STATISTICA 6. The statistical analysis of the data / A. A. Halafyan. - M.: Open Company «Binompress», 2007. $-512 \mathrm{p}$.

9. Haritonova L. G. Displasy of a connective tissue and its importance in the course of physical training and playing sports culture / L. G. Haritonova // The Theory and physical training practice. -2010 . - N 7. - P. 29-33.

10. Shian V. M. The theory and methods of physical education of pupils. P.1. / V. M. Shian. - Ternopol : Navthchalna kniga, 2012. - P. 224-233.

11/ Garcia-Campayo J. Joint hypermobility and anxiety: the state of the art / J. Garcia-Campayo , E. Asso, M. Alda // Curr. Psychiatry Rep. - 2011. - Vol. 13(1). - P. 1825.

12. Grahame $R$. The revised criteria for the diagnosis of benign joint hypermobility syndrome (BJHS) / R. Grahame, H. A. Bird, A. Child / / J. of Rheumatology. - 2000. - Vol. 27, N7. - P. 1777-1779.

13. Knee function in 10-year-old children and adults with generalised joint hypermobility / B. Juul-Kristensen, H. Hansen, E. B. Simonsen [et el.] // Knee. - 2012. - P. 12. 